\title{
From sidewalk ballet to defending the city
}

Maria del Carmen Mota Utanda

Universidad de Castilla-La Mancha, Spain

Carmen.Mota@uclm.es

\begin{abstract}
The city is primarily a public space as it is both a condition and an expression of its citizens. It is the environment where citizens can and should feel as such: free, equal and different. It is where society is performed, where it represents itself and is shown as a community that cohabitates and shows its contradictions, disputes and differences.

The city is where collective memory is created and where all the different identities emerge. For this reason, this is the ideal location for Humanae. The faces of thousands of citizens crowding halls and museums to conquer the squares. From the streets of a marginalized neighborhood in Málaga - Spain, or the Rotary Praça in São Paulo - Brazil, to a building at United Nations Habitat III and the entrance of the World Economic Forum in Davos, Humanae uses public space to involve citizens from all over the planet in a global dialogue.
\end{abstract}

Keywords: city, citizens, difference, identities, art

\section{To cite this article:}

Mota Utanda, M. (2018). From sidewalk ballet to defending the city. The Journal of Public Space, 3(2), 97-II4, DOI I0.3289I/jps.v3i2.IIII

This article has been accepted for publication in The Journal of Public Space. Please see the Editorial Policies under the 'About' section of the journal website for further information.

(c) (1) This work is licensed under a Creative Commons Attribution - Non Commercial 4.0 International License https://creativecommons.org/licenses/by-nc/4.0/ 
"When I get home after work, the ballet is reaching its crescendo. This is the time of roller skates and stilts and tricycles, and games in the lee of the stoop with bottletops and plastic cowboys; this is the time of bundles and packages, zigzagging from the drug store to the fruit stand and back over to the butcher's; this is the time when teen-agers, all dressed up, are pausing to ask if their

slips show or their collars look right; this is the time when beautiful girls get out of MG's;

this is the time when fire engines go through; this is the time when anybody you know around Hudson Street will go by."

This is Jane Jacob's famous "sidewalk ballet"; a dance that never repeats itself from place to place because its merging-of styles, buildings, functions and, of course, citizens-does not represent chaos, as argued by modern urbanism theory, but rather a complex and highly developed form of order. The journalist, urbanist and socio-political activist, whose centenary was recently celebrated the world over, defended the value of bringing together distinctive elements to create, not a dance of exactness and uniformity, but rather an intricate ballet whose defining characteristics are clearly illustrated by each of its parts, coming together to create one wonderful, harmonious and orderly whole. A young boy speeding past on his tricycle with his curly hair blowing in the breeze, with what we could call a café-au-lait complexion; a teenager with a more hazelnut-brown skin colour; a firefighter perched on top of his engine with a remarkable skin tone resembling strawberry bubble gum. A real mishmash. Or perhaps not. Because beneath the seeming disorder of the diverse city lies a marvellous order that cannot be achieved by attempts at homogenisation.

Jacobs, author of "The Death and Life of Great American Cities", which was described by the New York Times as perhaps the most influential work in the history of city planning, managed to save NYC's Washington Square Park from its fate as a highway intersection and preserve the area for pedestrians. Her book advocates diversity, not as a reality, but as the best version of such reality.

\section{The Venice Biennale and the Freespace manifesto}

In the same vein, it is no surprise that the most high-profile events in the urban planning calendar, such as the Venice Biennale or the European Prize for Urban Public Space, evaluate civic initiatives aimed at strengthening the city's function as a public space and a place of encounter. This explains the commitment to a philosophy of the creative process that is based on the meeting of words and ideas. The main objective of these events is to achieve a type of architecture that combines its artistic dimension with a mission to meet human, material and symbolic needs.

Within this context, in June 2017 the Freespace manifesto was published. It is a reference point for all those participating in the Venice Biennale, an exhibition of a truly mammoth scale, leading to an understanding of the city as a product of history and culture, as opposed to an entity or an evolving natural object. This is because, as already defended by Ortega y Gasset, the essence of a city is not its nature, which man changes at whim to adapt it to his needs, but rather its history, the marks left behind by its contingencies. Discovering cohesion amid diversity and chaos. This is one of the ideas of the manifesto, where the use of dance as a metaphor, over fifty years after Jacob's work was released, appears to be no accident: 
"We are interested in going beyond the visual, emphasizing the role of architecture in the choreography of daily life. . . We see the earth as Client. This brings with it long-lasting responsibilities. Architecture is the play of light, sun, shade, moon, air, wind, gravity in ways that reveal the mysteries of the world. All of these resources are free. . .

We believe these qualities sustain the fundamental capacity of architecture to nurture and support meaningful contact between people and place. We focus our attention on these qualities because we consider that intrinsic to them are optimism and continuity.

Architecture that embodies these qualities and does so with generosity and a desire for exchange is what we call Freespace."

Just before reaching its conclusion, the manifesto invites all participants to bring their Freespace to Venice, so that together we can discover the diversity, particularity and continuity of a kind of architecture that is based on people, place, history and time, in order to support culture and the importance of architecture on our dynamic planet. People, place, time, history... we've almost arrived to Humanae.

\section{Humanae: Work in Progress. The planning behind the project}

Angélica Dass' Humanae: Work in Progress is conceived as a tool for exploring, questioning and searching for identity, both one's own and that of others, using photography to set up a dialogue. A game whereby social and personal codes are proposed for reinvention; a constant circular flow between the photographer and the photographed; a bridge between masks and identities.

The project champions diversity; however, it manages to do so in a new way, presenting images of real people, minus any airbrushing, which show their naturalness in its purest state. The project has received coverage in the media- appearing in a TED Talk and on the cover of Foreign Affairs- and has been made available in the urban space, being featured in museums all over the world. Dass's work is being used as a genetic research tool for Milan's Leonardo da Vinci National Science and Technology museum in its genetics section and as a school project in countless primary schools for studying the topic of diversity. The formats are nearly as varied as the colours of the portraits, with one purpose as an objective: encourage the viewer to recognise and embrace differences for what they are: a good thing that makes each one of us unique and special.

This creative concept is paired with a rigorous and systematic process: each photo is set against a background that matches the colour of an II-by-II-pixel sample taken from the model's face. Lined up just like in a colour sample book, horizontality is not only a formal feature: it also has an ethical dimension. In this way, with extraordinary simplicity, the false supremacy of certain races over others fades away; it is enough to "innocently" move the issue of race out of the socio-political context into an innocuous environment, that of a colour chart, where the primary colours are just as important as the blended colours.

However, the idea of "work in progress" is not random; it is a potentially never-ending project aimed at doing away with the colour codes associated with race, while inviting a reflection on equality that goes on to subtly become a plea for diversity, which its creator has experienced first-hand. Dass's multiracial background, typical in Brazil, means that her body comprises many colours: "I have indigenous, African and Portuguese blood. I always saw all of these colours represented within me and, although they were different, they 
were treated the same. I try to bring this idea of equality that I learnt in my multicolour family into the world".

Unlike most photo projects, viewed only at exclusive events held by the circles in which they are created, since its inception Humanae has had a vocation to be open to the world and thanks to its critical and thought-provoking content, ended up, quite naturally, transcending the boundaries of photography. The fact that a selection of Humanae portraits once appeared on the front of the building hosting the 2017 Davos World Economic Forum is a clear testament to this.

\section{Defending the city, public life and difference}

Humanae, in its multiple versions, takes the city by storm. And it does so from the understanding that the city is not just a place; its value is not based solely on its buildings and scenery, but can be found in the people who inhabit it. Dass photographs a huge number of local people who stand up for, by appearing in the portraits, the beauty of the natural.

Dass, Jacobs and the Freespace manifesto are defenders of communal life; they contend that therein lies the solution to so many contemporary issues. Getting to know your neighbours, forming networks, mixing with different people, greeting each other and being able to laugh again, we can do all of these things in the public space, the authentic and complex social institution where from childhood we learn to socialise and build communities.

Humanae is boundary-breaking on many fronts: by getting featured in museums from all the world, it leaves behind the more traditional territory of photography and takes to the streets, which for Dass means that, beforehand, one should have a deep understanding of the city and the public space in question, and know where to find its spirit, how residents use it, what they like about it, what activities they perform in its streets. Only then can the right dimensions, the appropriate layout and the ideal perspective be achieved. Essentially, a prior understanding of the place is required, which is why we have to walk around the city, talk to its people, see how it fosters the wonderful interweaving of relationships, links and encounters between its inhabitants. Ultimately, Humanae favours the public space as the best catalyst for achieving its objectives; it manages to elevate its status to being at the very heart of modern life. It compels prior understanding to trigger action, from a place of utmost respect. It humanises the public space and promotes the experience of contact, exchange and difference, through portraits of the people that bring life to it. No labels and no standardisation, as this is the way to improve, not only our cities, but our world.

\section{The city and the championing of diversity: work in progress}

Building a positive discourse around diversity by involving a growing number of people is an endeavour that is destined to go on indefinitely, just like the battle for the best kind of city. A never-ending journey lies ahead for this project which brings together artistic, anthropological, sociological and sentimental values. Just like the city itself, just as our own experience shows us, to quote Borges "We are our memory, we are that chimerical museum of shifting shapes". Our memory, what we are and what we come from, makes every cell in our body unique, and by cell, we also mean pixel. 


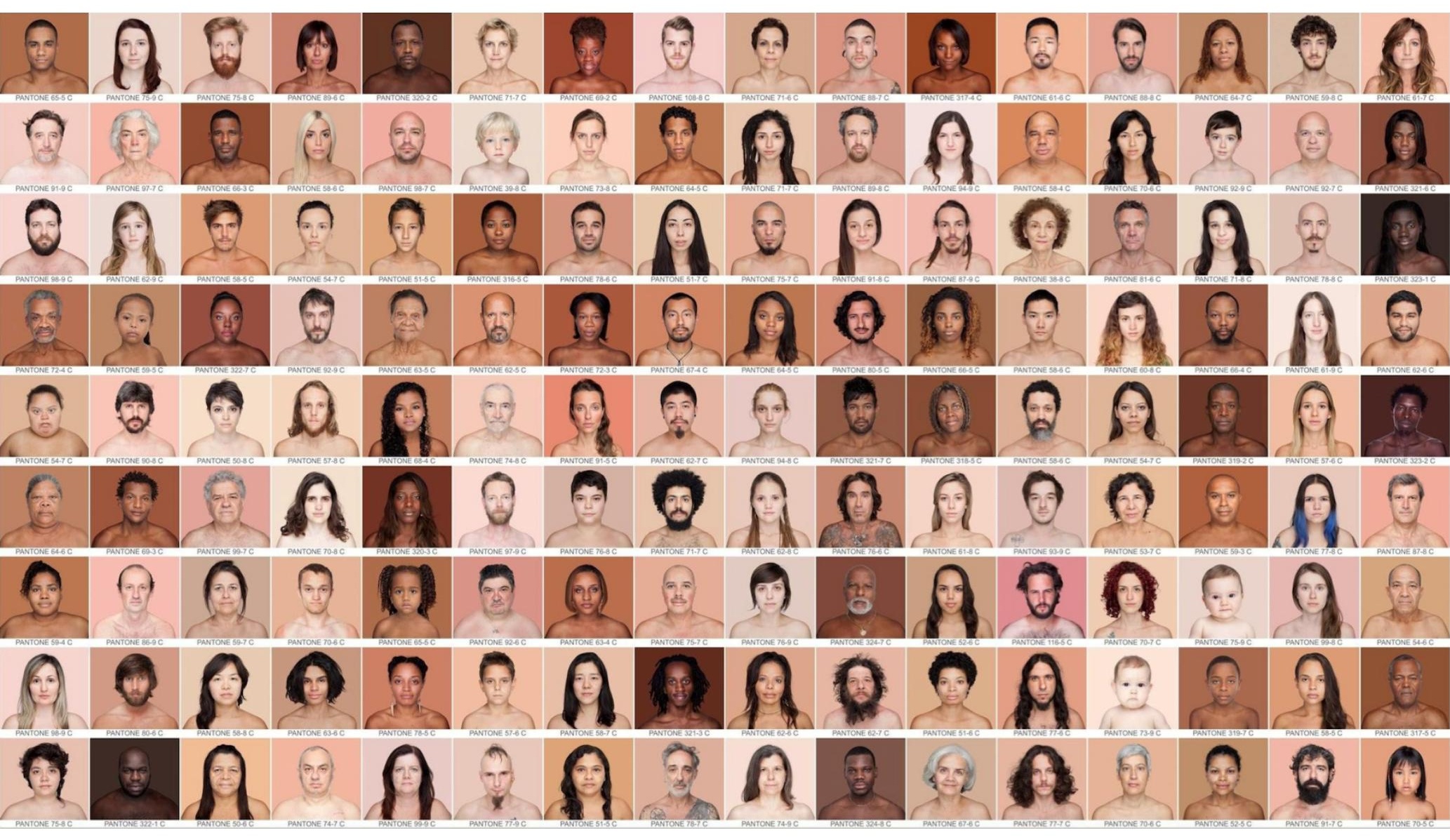

Humanæ is a photographic work in progress by artist Angélica Dass, an unusually direct reflection on the color of the skin, attempting to document humanity's true colors rather than the untrue labels "white", "red", "black" and "yellow" associated with race. It's a project in constant evolution seeking to demonstrate that what defines the human being is its inescapably uniqueness and, therefore, its diversity. The background for each portrait is tinted with a color tone identical to a sample of II $x$ II pixels taken from the nose of the subject and matched with the industrial pallet Pantone $®$, which, in its neutrality, calls into question the contradictions and stereotypes related to the race issue. More than just faces and colors in the project, there are almost 4,000 volunteers, with portraits made in 26 different countries and 28 different cities around the world, thanks to the support of cultural institutions, political subjects, governmental organizations and non-governmental organizations. The direct and personal dialogue with the public and the absolute spontaneity of participation are fundamental values of the project and connote it with a strong vein of activism. The project does not select participants and there is no date set for its completion. From someone included in the Forbes list, to refugees who crossed the Mediterranean Sea by boat, or students both in Switzerland and the favelas in Rio de Janeiro. At the UNESCO Headquarters, or at a shelter. All kinds of beliefs, gender identities or physical impairments, a newborn or terminally ill, all together build Humanae. All of us, without labels. www.humanaeproject.org

Humanae Video - https://vimeo.com/2802217/3 


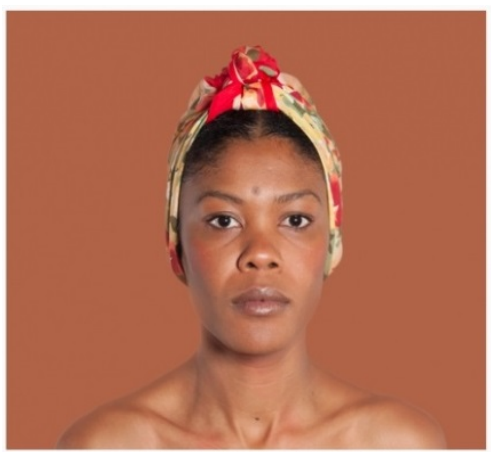

PANTONE $7522 \mathrm{C}$

1979, Rio de Janeiro, Brazil. Lives and works in Madrid.

Angélica Dass is an award-winning photographer living in Madrid, Spain. Originally from Rio de Janeiro, Brasil, she is acutely aware of how small differences in skin tone can swell into large misconceptions and stereotypes about race. She is the creator of the internationally acclaimed Humanæ Project, a collection of portraits that reveal the diverse beauty of human colors. The initiative has traveled to more than 30 countries across six continents - from The World Economic Forum in Davos to the pages of National Geographic - to promote dialogue that challenges how we think about skin color and ethnic identity.

In 2016, her career launches to new dimensions with her TED Global Talk, confirming the great potential of her work to go beyond photography, becoming a tool for social change, which promotes dialogue and challenges cultural prejudices. Today, this TED talk exceeds two million views. As part of the TED Residency 2018, she presents her new talk which will be seen online in October 2018.

Angélica's work transcends the museums and finds in school classrooms a great universe of work. She amplifies the educational message of Humanae through institutional collaborations around the world, such as collaborations with city councils of different cities in the Basque Country, teacher training schools in Madrid, highschools in the Czech Republic, or with UNESCO and the Government of Chile, reaching an impact of more than 50 thousand students in a week. She is also a powerful and inspiring speaker who has lectured at important organizations, such as the University of Salamanca, the University of Bologna, or the UERJ - Rio de Janeiro; as well as the International Congress of Fundraising - The Resource Alliance, at National Geographic and at the World Economic Forum, as a cultural leader.

This career path leads Angélica to fund the Humanae Institute, a non-profit educational platform with the objective to position diversity as a value in the educational process.

http://www.angelicadass.com/humanae/

TED Talk 2016

https://www.ted.com/talks/angelica_dass_the_beauty_of_human_skin_in_every_color?nolanguage 


\section{World Economic Forum, Promenade Entrance}

Davos, Switzerland

January 2017

Humanae was exhibited with a large-scale outdoor installation intended to remind participants of the diversity of the human condition and to inspire more responsive and responsible leadership.

The World Economic Forum partners with international cultural and scientific organizations to engage world leaders on how to empower young people and enable their creativity to meet the challenges of the Fourth Industrial Revolution'.

In January 2017, Dass became the first visual artist to be featured at the World Economic Forum Annual Meeting's promenade entrance, a fact that highlights the impact of Humanae's outdoors exhibits.

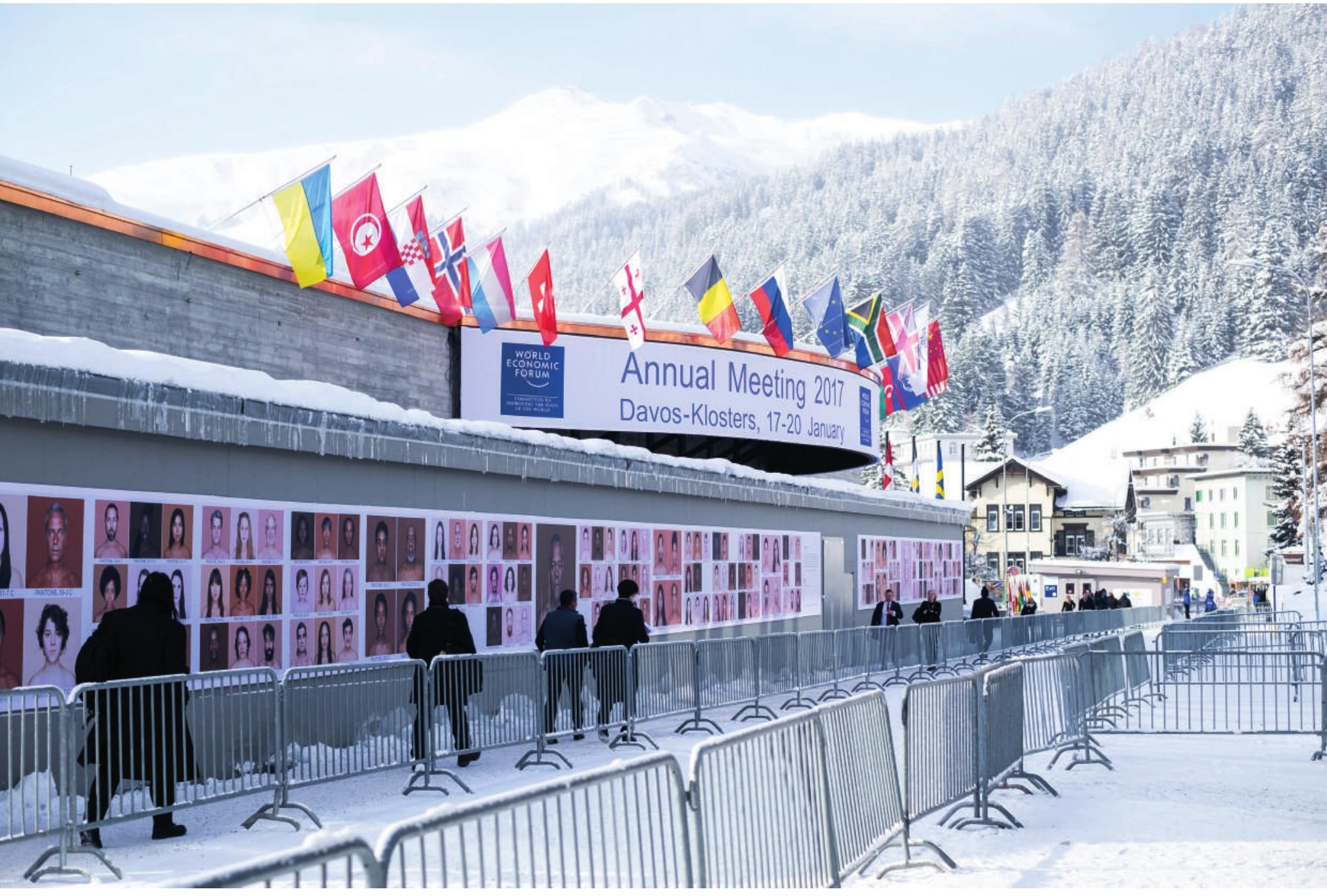

I. https://www.weforum.org/agenda/2016/0I/the-fourth-industrial-revolution-what-it-means-and-how-to-respond 


\title{
Biennale dell'Immagine
}

\author{
Chiasso, Switzerland
}

October 2017

Since 2004, the participation of Chiasso_Culture in movement at the Biennale dell'Immagine is characterized by the promotion of site-specific artistic projects, designed and realized to directly involve the citizens of Chiasso and to publicly discuss issues of great social importance.

For the tenth edition, the Hispano-Brazilian artist Angélica Dass was invited to Chiasso. The experience of Humanæ in Chiasso was developed over an extended period of time and was articulated in a series of complementary activities, according to a practice common to many public art works in which the aesthetic, the relational and the educational and didactic aspects constitute equal and fundamental elements of the work. The project was implemented through three main stages: the Week Against Racism (with the activation of a temporary photographic studio, children's workshop and a public lecture); the School Workshop Series (a series of laboratories on the perception of skin color, with the involvement of almost 100 students of primary and secondary schools in Chiasso); and the Outdoors Installation during the Biennale dell'Immagine (presenting the portraits made in Chiasso, together with others from the Humanæ archive) and and Indoors Exhibition at the Workshop Space (presenting the results of the children's workshops). The three stages compound a unique Humanae Experience where all activities became a place of meeting, knowledge and dialogue.

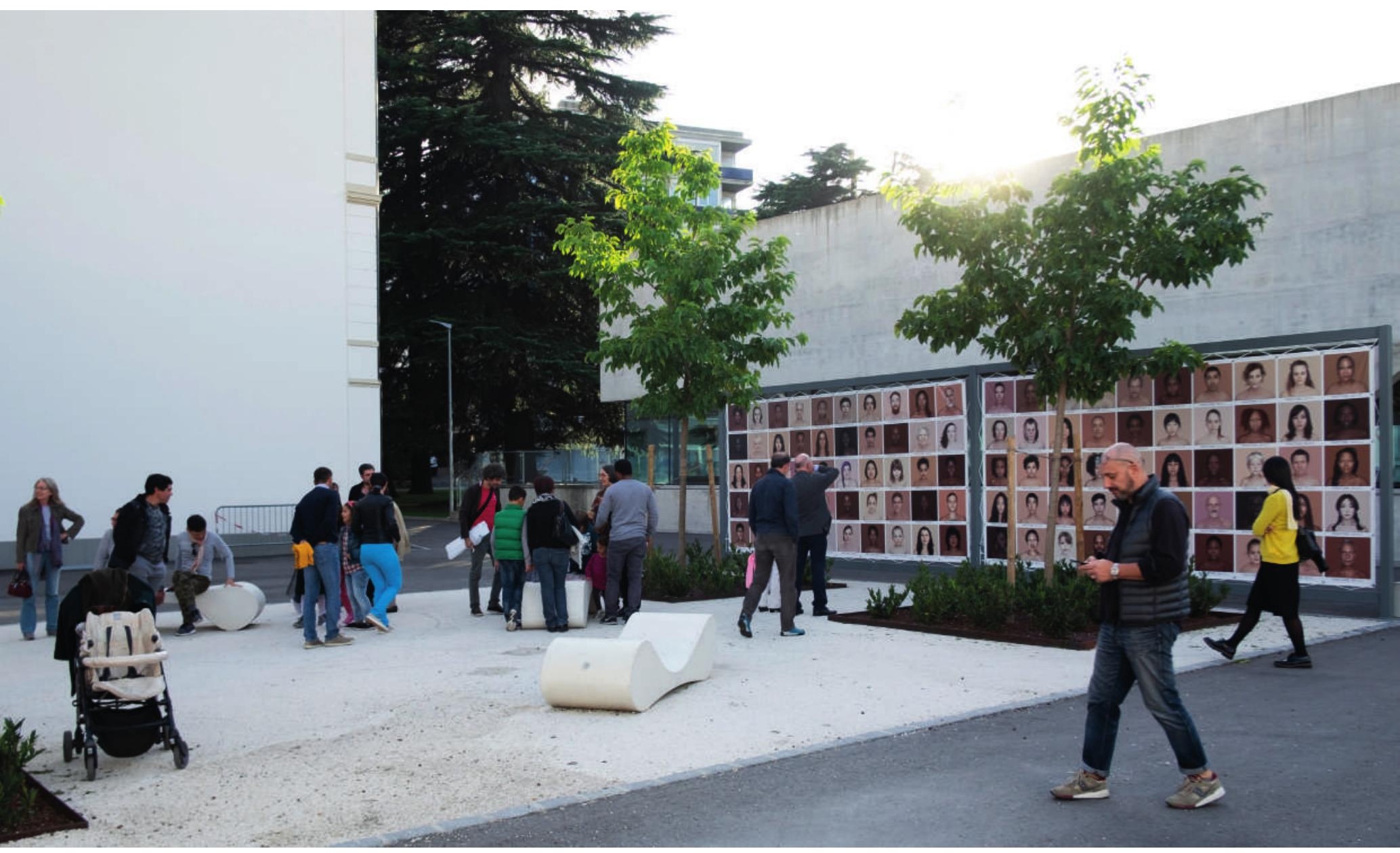

104 | The Journal of Public Space, 3 (2), 2018 | ISSN 2206-9658

City Space Architecture / UN-Habitat 

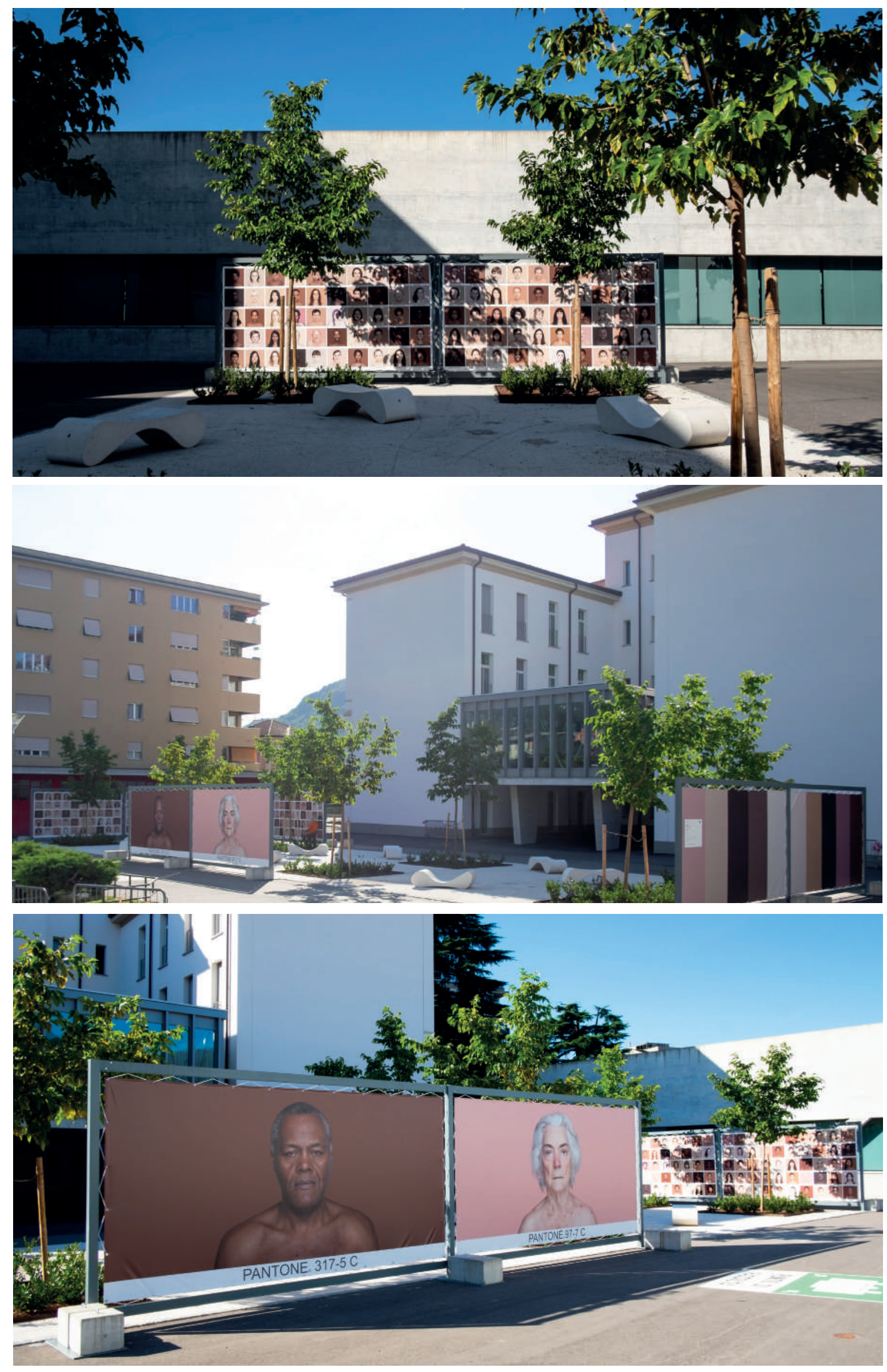

I05 | The Journal of Public Space, 3 (2), 2018 | ISSN 2206-9658 City Space Architecture / UN-Habitat 


\section{United Nations' Habitat III Conference, Arbolito Park}

Quito, Ecuador

October 2016

In Habitat III, the United Nations Conference on Housing and Sustainable Urban Development, at the Quito pavilion, Humanae's most prominent exhibition was presented with a projection of 160,000 lumens in a $12 \times 12$ meter cube. Each of the 64 portraits measured around 3 meters. According to the $\mathrm{UN}$, the conference took place "to revitalize the global commitment to sustainable urbanization, to focus on the implementation of a 'New Urban Agenda', where diversity is a fundamental issue".
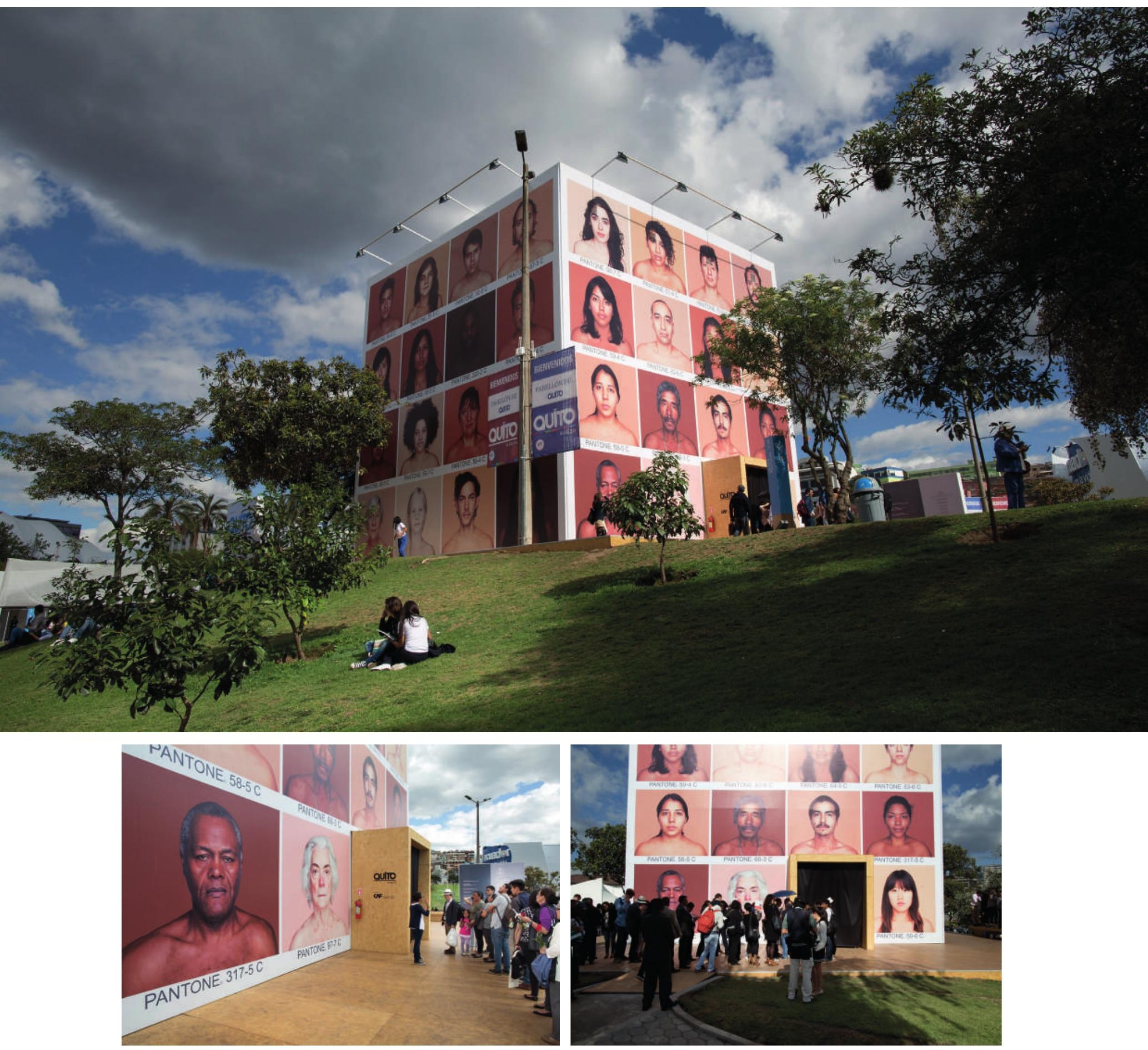

106 | The Journal of Public Space, 3 (2), 2018 | ISSN 2206-9658

City Space Architecture / UN-Habitat 

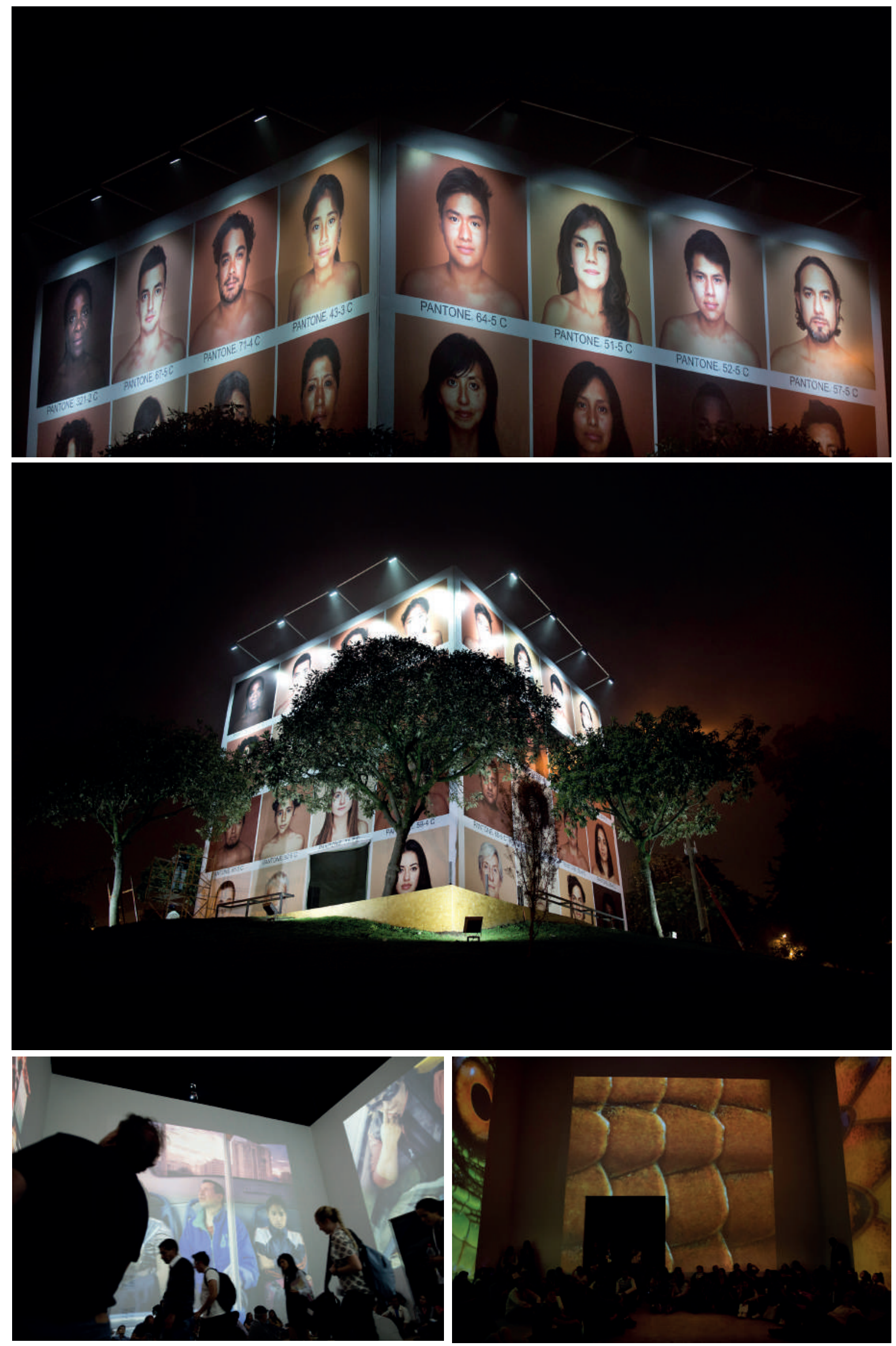

All pictures for the UN Habitat III Conference Humanae installation are from Edu León.

I07 | The Journal of Public Space, 3 (2), 2018 | ISSN 2206-9658 City Space Architecture / UN-Habitat 


\section{Paseo Uribitarte}

Bilbao, Spain

March 2016

Commemorating the International Day Against Racial Discrimination (March 2 Ist), Humanae was invited to the cities of Bilbao. For this public installation, Dass collaborated with the City Council of Bilbao, and made an open call for citizens to volunteer and neighbors. The selected images formed a mosaic of local faces, together with others from the Humanæ world archive, exhibited in six large cubes bordering a pedestrian area of Paseo Uribitarte between the Pio Baroja station and the Zubizuri Bridge. Bilbao is part of the Intercultural Cities Project (ICC) of the Council of Europe through the REClNetwork of Intercultural Cities, a model of a city that works for equal rights, duties and social opportunities for people who inhabit them, preventing and questioning prejudices linked to immigration, refugee and cultural diversity, and promoting an environment more prone to intercultural coexistence and to the prevention of discrimination and racism. In this context, Humanae represented all the positive values embodied by the intercultural project and the commemoration of March 2 Ist.

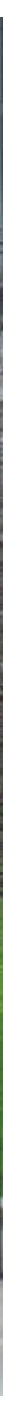

108 | The Journal of Public Space, 3 (2), 2018 | ISSN 2206-9658

City Space Architecture / UN-Habitat 

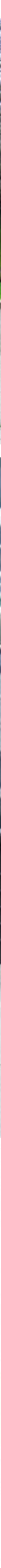
From sidewalk ballet to defending the city
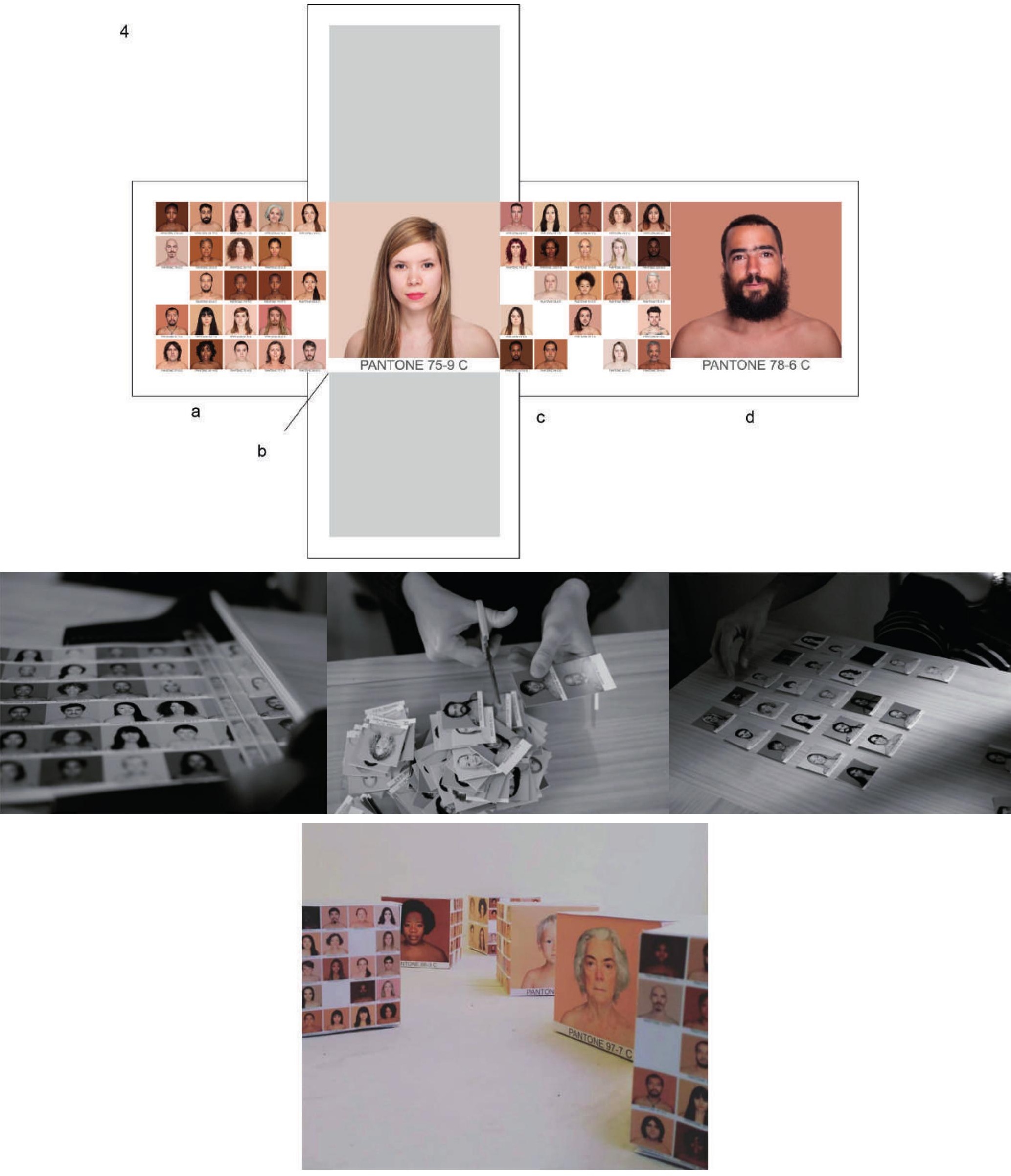

I 10 | The Journal of Public Space, 3 (2), 2018 | ISSN 2206-9658

City Space Architecture / UN-Habitat 


\section{Urban Layers Project}

Lecce, Gibellina, Cinisello Balsamo (Milano), Italy

Málaga, Spain

Thessaloniki, Greece

June 2016

With a traveling exhibit, Humanae was part of the Urban Layers - New Paths in

Photography, an European Project about photography in the public space, which aims are bringing contemporary art to a wider audience, promoting photographic research and supporting emerging artists. The project was funded by Creative Europe Culture Program - Cooperation Projects, encouraging a broad audience to take part in the cultural development of its territory through an active participation through the use of photography as a form of public and shared art.

Humanae prints traveled between Italy, Spain and Greece, being exhibited in different outdoors and indoor spaces at the Università del Salento in Lecce; Fondazione Istituto di Alta Cultura Orestiadi onlus in Gibellina - Trapani; Fondazione Museo di Fotografia Contemporanea in Cinisello Balsamo (Milano);Arte Contemporáneo GACMA in Málaga; and during the Thessaloniki Museum of Photography's PhotoBiennale.

The challenge of this project was to adapt the same print for the different structures that would be exhibited in different outdoors and indoor spaces in Italy, Spain and Greece. The outdoor exhibitions were held in Malaga, at the Neighborhood of Lagunilla during the UPHO Festival; and at the Seafront Promenade of Thessaloniki, in collaboration with Thessaloniki Museum of Photography, during the PhotoBiennale.

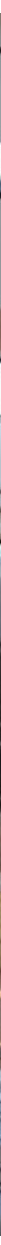

II I | The Journal of Public Space, 3 (2), 2018 | ISSN 2206-9658 City Space Architecture / UN-Habitat 

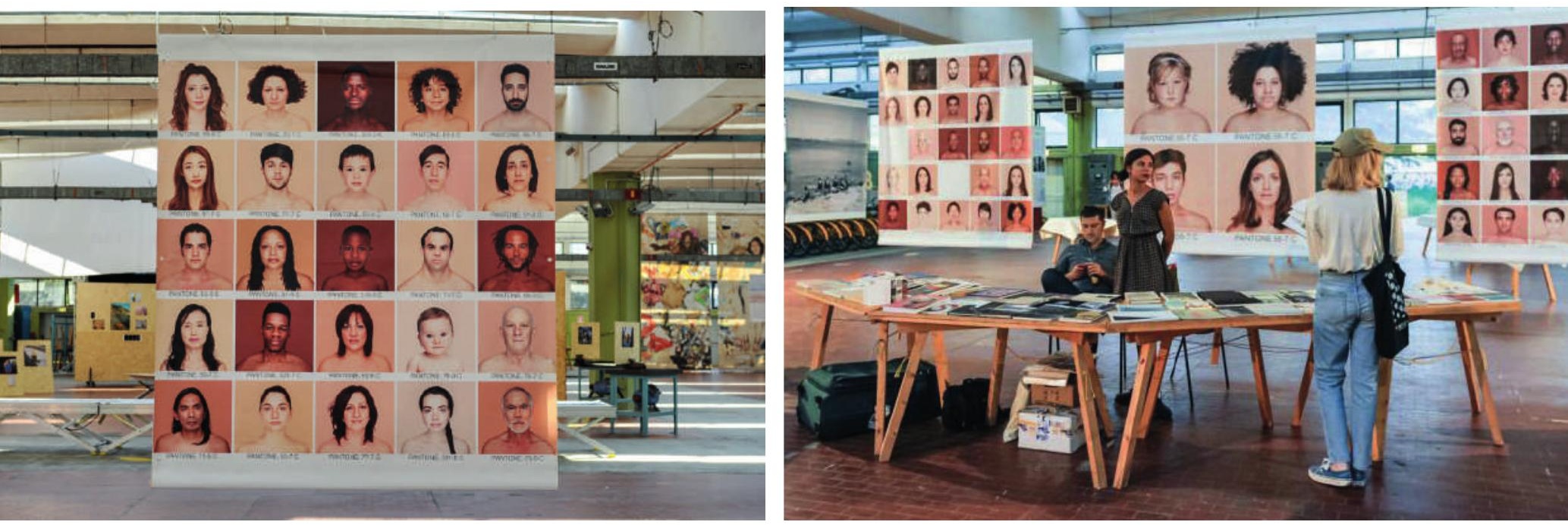

BITUME Photofest, Lecce, Italy. Pictures by Alice Caracciolo.

\section{Identity Flows}

Visual Routes Across the Mediterranean Sea
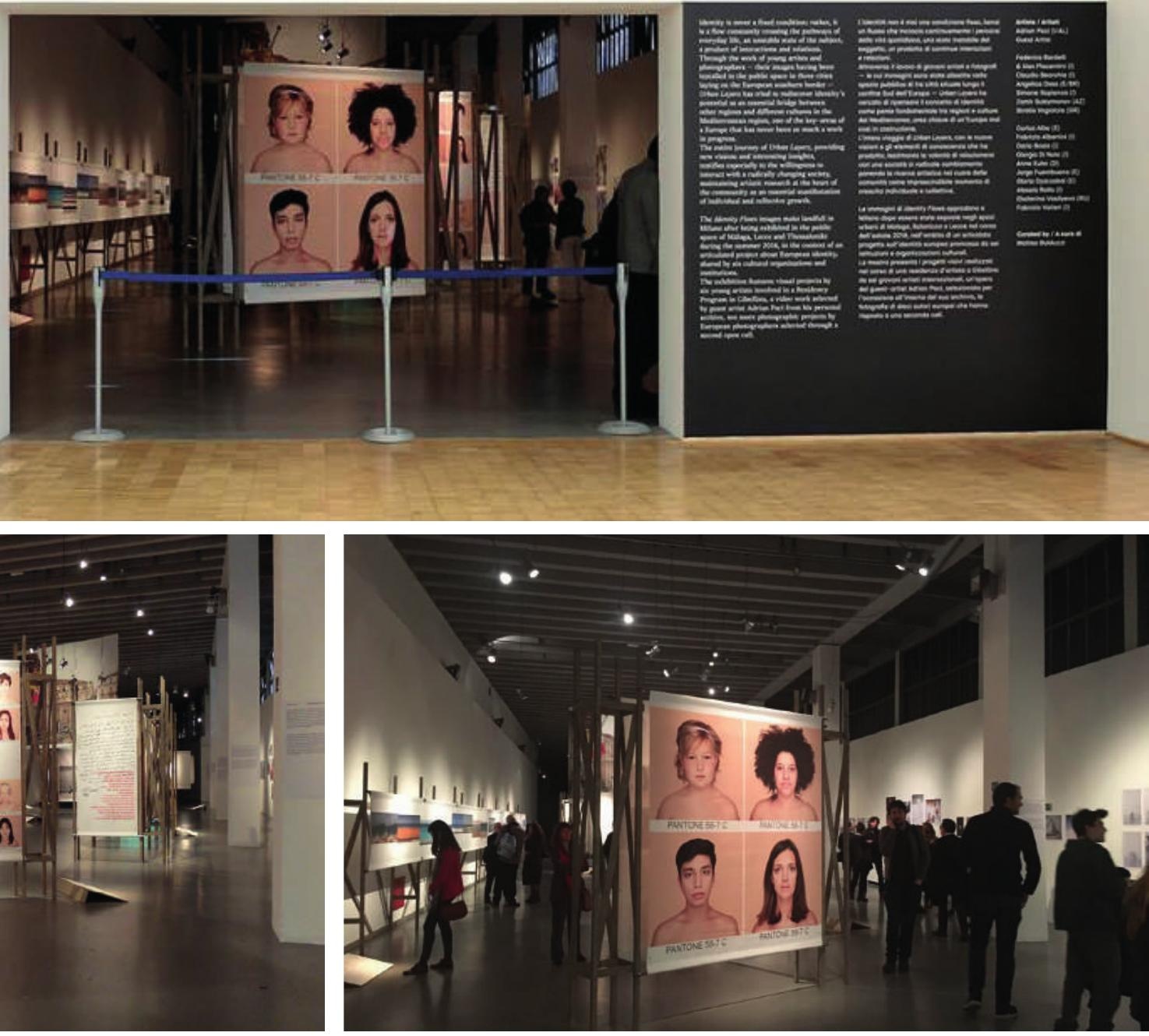

MUFOCO - Museum of Contemporary Photography, Triennale di Milano, Italy.

II 2 | The Journal of Public Space, 3 (2), 2018 | ISSN 2206-9658

City Space Architecture / UN-Habitat 


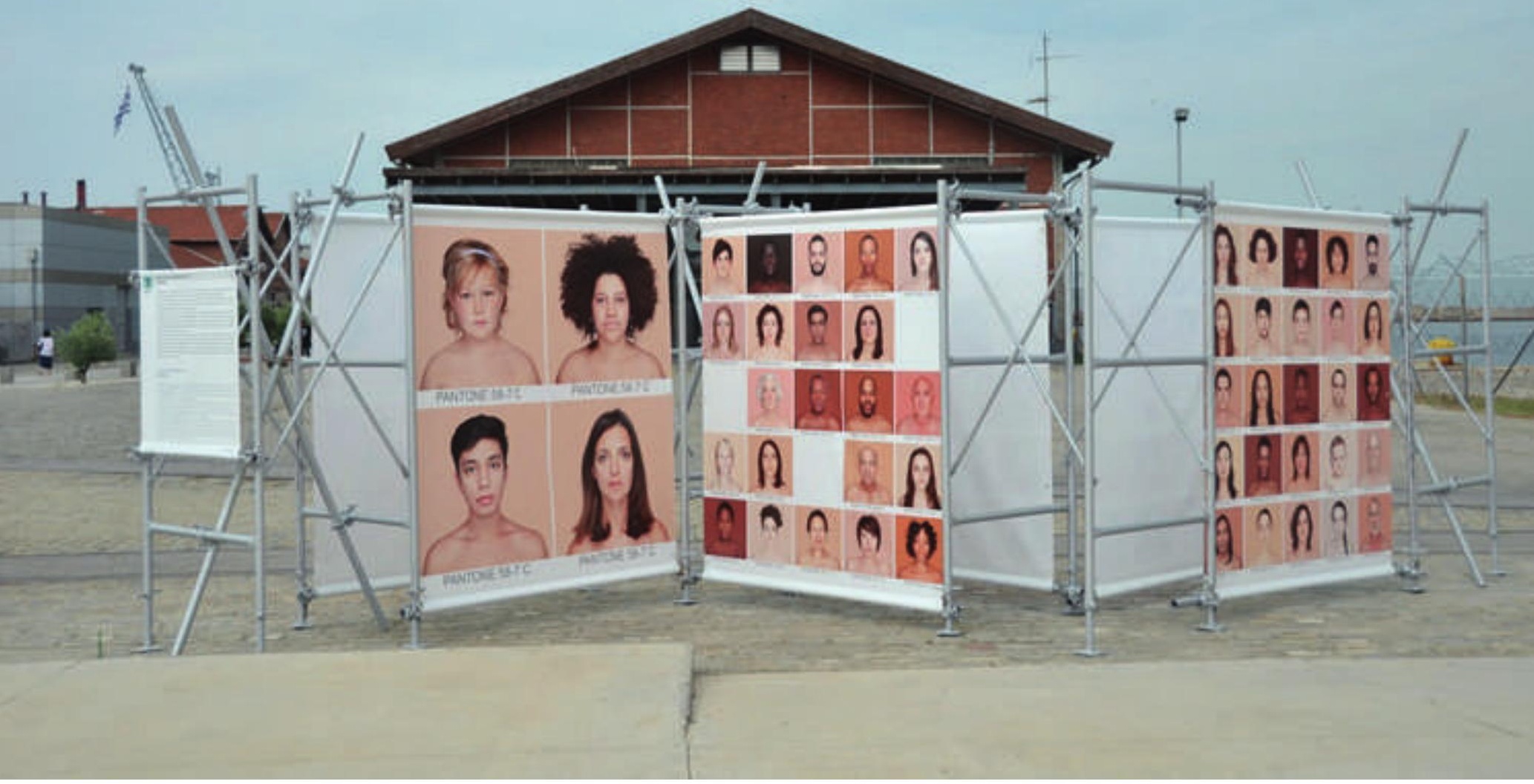

Thessaloniki Museum of Photography's PhotoBiennale, Greece.

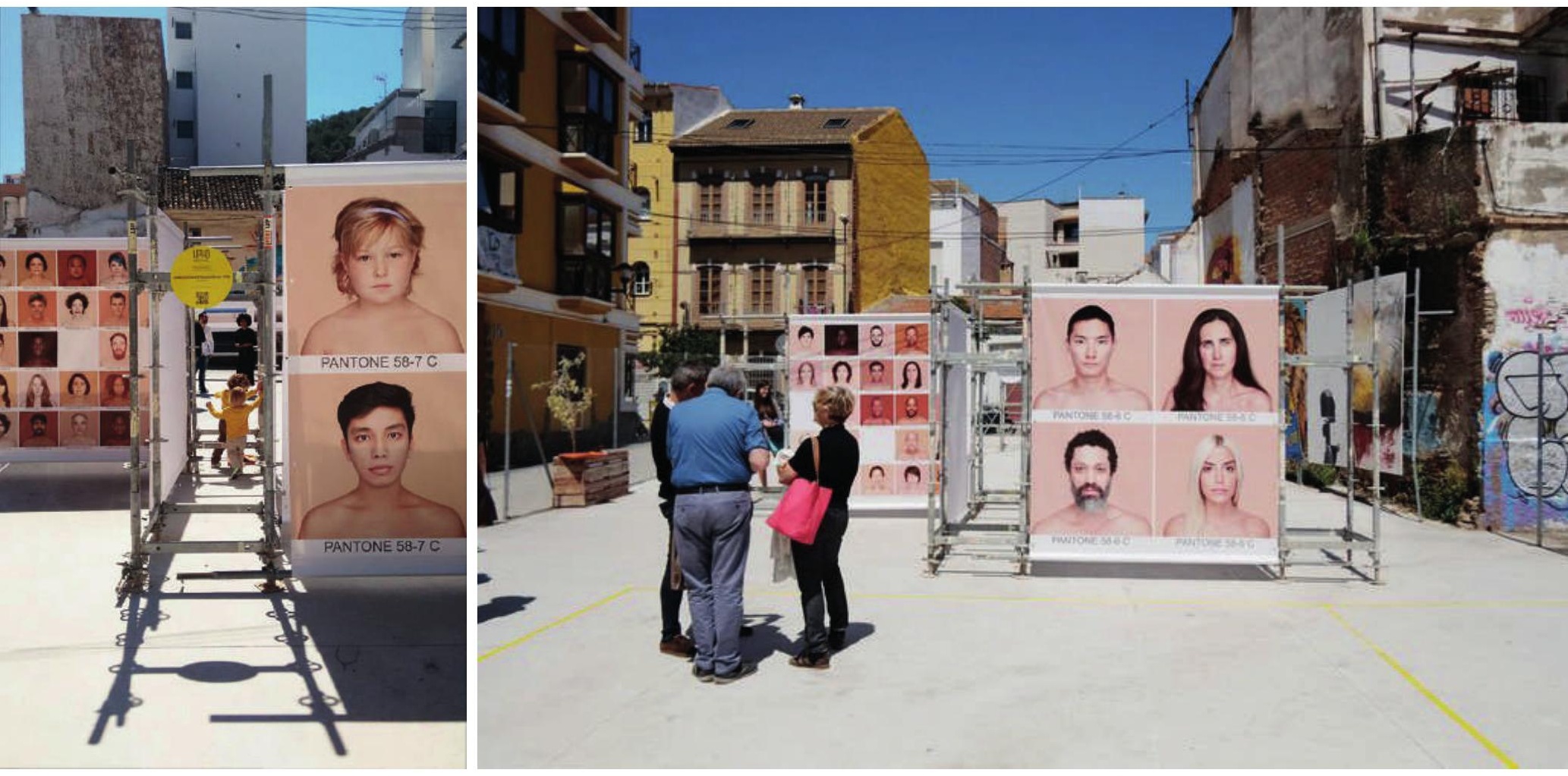

UPHO Festival, Málaga, Spain.

II3 | The Journal of Public Space, 3 (2), 2018 | ISSN 2206-9658 


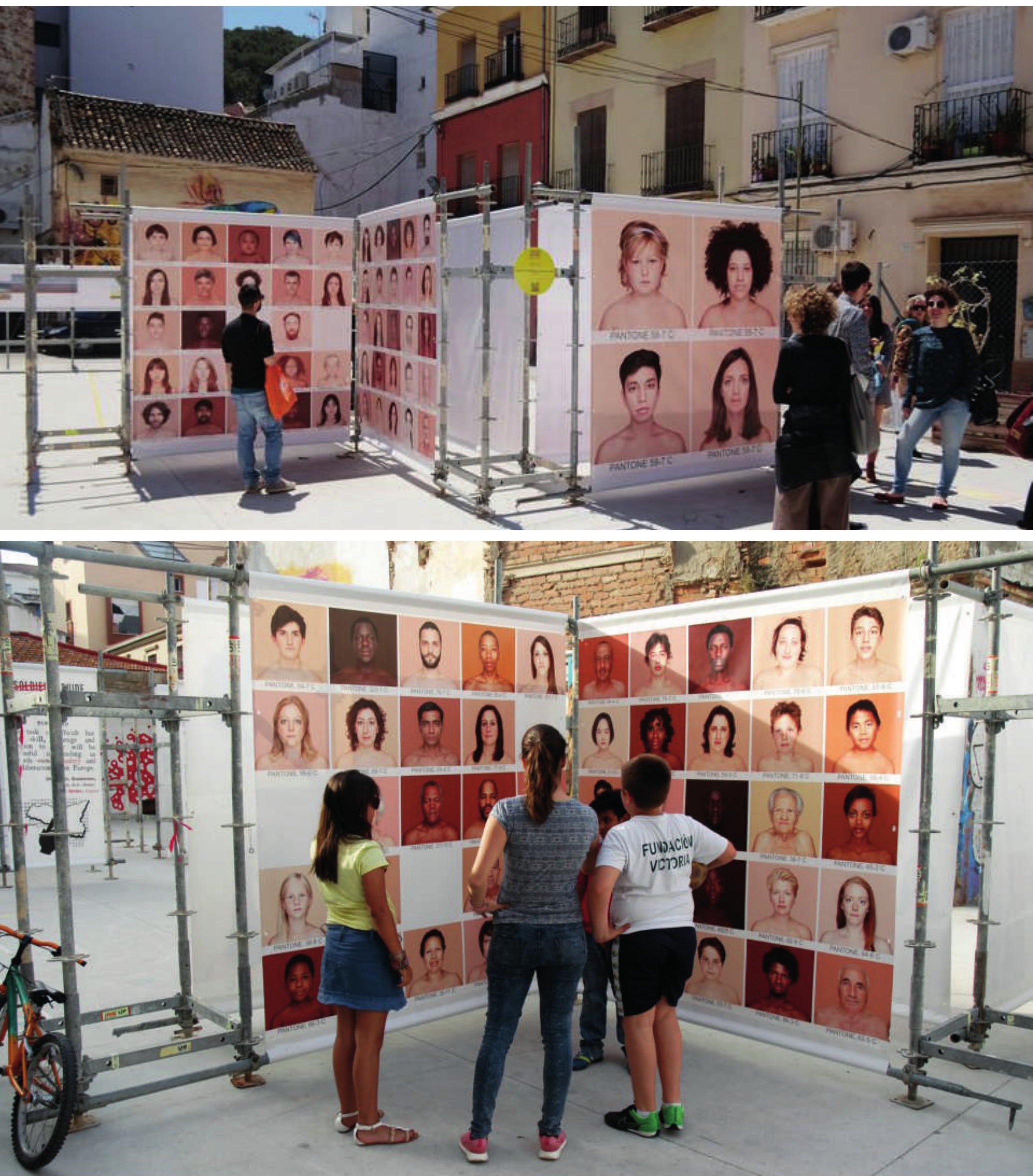

UPHO Festival, Málaga, Spain.

Il4 | The Journal of Public Space, 3 (2), 2018 | ISSN 2206-9658

City Space Architecture / UN-Habitat 